\title{
Variasi Komposisi Bahan pada Pembuatan Briket Cangkang Kelapa Sawit (Elaeis guineensis) dan Limbah Biji Kelor (Moringa oleifera)
}

\author{
Wahyu Rizqi Wicaksono dan Sri Nurhatika \\ Departemen Biologi, Fakultas Ilmu Alam, Institut Teknologi Sepuluh Nopember (ITS) \\ e-mail: nurhatika@yahoo.com
}

\begin{abstract}
Abstrak-Peningkatan kebutuhan energi yang tidak seimbang dengan jumlah sumber energi yang ada, memacu adanya energi alternatif dengan nilai yang lebih ekonomis. Salah satu energi alternatif adalah briket yang merupakan jenis bahan bakar yang berasal dari limbah organik sehingga menurunkan biaya produksi menjadi lebih rendah. Metode penelitian ini diawali dengan proses pengarangan bahan, kemudian dilakukan pembuatan briket dengan variasi komposisi yang telah ditentukan. Kemudian briket di analisis meliputi uji kadar air, kadar abu, kadar zat hilang, fix karbon, uji kalor dan laju pembakaran . Pada uji kadar air didapat hasil terbaik $0.27 \%$ pada berbandingan 0\%:100\% (cangkang:biji), pada uji kadar abu hasil terbaik $1.81 \%$ pada berbandingan $0 \%: 100 \%$ (cangkang:biji), pada uji kadar zat hilang didapat hasil terbaik $29.81 \%$ pada perbandingan $100 \%: 0 \%$ (cangkang:biji), pada uji fix karbon didapat hasil terbaik $40.93 \%$ pada berbandingan 0\%:100\% (cangkang:biji), pada uji kalor didapat hasil terbaik 5126.1 pada perbandingan 100\%:0\% (cangkang:biji) dan pada uji laju pembakaran didapat hasil terbaik $0.097 \mathrm{~g} / \mathrm{s}$ pada berbandingan 0\%:100\% (cangkang:biji).
\end{abstract}

Kata Kunci-Biji Kelor, Briket, Cangkang Kelapa Sawit, Energi Alternatif.

\section{PENDAHULUAN}

$S^{\prime}$ UMBER energi saat ini memegang peranan penting dalam pengembangan ekonomi nasional [1]. Peningkatan kebutuhan energi di Indonesia dari tahun ke tahun berdampak pada ketersediaan cadangan energi fosil seperti bahan bakar minyak, gas bumi, dan batu bara yang semakin berkurang [2], sehingga sekarang banyak dilakukan penelitian terkait sumber energi alternatif dalam memenuhi kebutuhan energi di Indonesia [3]. Salah satu energi alternatif yang dikembangkan saat ini adalah briket yang merupakan suatu jenis bahan bakar padat yang berasal dari biomassa maupun limbah bahan organik yang dapat menghasilkan kalor sebesar > $4.000 \mathrm{kal} / \mathrm{gr}$, gas metana, karbon, uap air sebesar $<7,5 \%$, dan belerang sebesar $<1 \%$ [4]. Sebagai salah satu bentuk bahan bakar baru, briket merupakan bahan yang sederhana, baik dalam proses pembuatan ataupun dari segi bahan baku yang digunakan, sehingga bahan bakar briket memiliki potensi yang cukup besar untuk dikembangkan. Pembuatan briket telah banyak dilakukan dengan menggunakan bahan yang berbasis biomassa, seperti briket biomassa tempurung kelapa, biji jarak, briket serbuk gergajian kayu [5][6][7].

Biomasa secara umum dikenal sebagai bahan kering material organik berasal dari tanaman atau kotoran hewan [8]. Data Indonesia Energi Outlook (2002) biomassa memiliki cadangan sebesar $434.000 \mathrm{GW}$ atau setara 255 juta barrel minyak bumi. Potensi biomassa ini sangat besar apabila dijadikan sumber energi alternatif khususnya untuk kebutuhan energi rumah tangga yang jumlahnya semakin sedikit. Sumber utama penghasil biomassa di Indonesia ada berbagai macam, yaitu dari sektor kehutanan, pertanian dan limbah pemukiman (kota). Limbah tersebut dapat diolah menjadi bahan bakar padat yang dapat digunakan sebagai bahan bakar alternatif yang yaitu briket [9]. Dari tanaman perkebunan, salah satu sumber daya biomassa yang paling melimpah adalah perkebunan kelapa sawit, selain itu terdapat sumber biomassa lain berupa biji kelor yang dapat dimanfaatkan sebagai biobriket [10].

Cangkang kelapa sawit memiliki kandungan lignoselulosa berkadar karbon tinggi dan mempunyai berat jenis yang lebih tinggi daripada kayu yang mencapai $1,4 \mathrm{~g} / \mathrm{ml}$, sehingga karakteristik ini memungkinkan bahan tersebut lebih baik untuk dijadikan arang [11]. Nilai energi panas cangkang kelapa sawit lebih tinggi yaitu 5.656 kalori/gr daripada limbah kelapa sawit pada bagian lain seperti serabut, dan tandan kosong [12]. Sedangkan biji tanaman kelor mengandung minyak kelor sekitar 30-40\% dari berat kering per biji kelor [13]. Besarnya kandungan tersebut, biji kelor dapat dimanfaatkan sebagai bahan biodiesel, sedangkan untuk aplikasi sebagai bahan campuran briket dapat meningkatkan energi panas dari bahan utama briket [14].

Biomassa merupakan bahan alami yang dapat digunakan sebagai sumber energi terbarukan yang berpotensi menghasilkan sekitar 25\% dari kebutuhan energi global [15]. Biomassa adalah istilah yang digunakan untuk bahan atau sisa dari makhluk hidup baik dari darat maupun laut [16]. Biomassa dapat diperoleh dari berbagai macam sumber, anatara lain biomassa pertanian dan biomassa hutan. Biomassa pertanian merupakan biomassa dari limbah pertanian seperti batang, daun serta produk sampingan dari pertanian yang dapat dijadikan sumber energi. Biomassa hutan merupakan biomassa yang didapatkan dari hutan seperti kayu [17]. Menurut Murtala, 2012 biomassa dapat diperoleh dari beberapa sumber, yaitu;

1) Limbah hewan: potensi biomassa dari limbah hewan merupakan limbah yang intensif berupa kotoran hewan.

2) Biomassa pertanian: biomassa pertanian yang dapat digunakan untuk memproduksi energi merupakan residu dari tanaman pertanian (batang, cabang, daun, jerami, serta limbah dari pemangkasan) dan biomassa dari limbah pengolahan produk pertanian (sisa dari pembuatan katun, ampas biji zaitun, dll). 
3) Biomassa hutan: biomassa hutan yang dapat digunakan untuk keperluan energi terdiri dari kayu bakar, residu hutan serta produk sampingan dari industri kayu.

4) Limbah perkotaan: limbah perkotaan umumnya dikenal sebagai sampah, merupakan kombinasi dari limbah cair dan padat. Limbah biasanya akan dipisah antara limbah yang dapat didegradasi dan limbah yang dapat di daur ulang atau dijadikan energi seperti sayuran atau limbah hijau dan kertas.

Biomassa merupakan sumber energi terbarukan yang saat ini dapat diterima oleh masyarakat luas. Penggunaan biomassa dari pertanian sebagai sumber energi dapat berkontribusi untuk memeajukan pembangunan dari sector energi Karena tidak ada persaingan dengan produksi pangan dan tidak ada prubahan tata guna lahan yang dibutuhkan [18].

Briket merupakan bahan bakar dalam bentuk padat yang dapat dibakar sebagai energi. Briket diproduksi dengan memadatkan residu biomassa menjadi balok padat yang dapat menggantikan bahan bakar fosil, arang dan kayu bakar alami untuk memasak dan proses pemanasan industri baik secara domestik maupun secara institutional [19]. Briket terbuat dari bahan yang murah atau bahkan tanpa biaya, seperti koran lama atau dari seresah atau sisa pengolahan tanaman [20]. Briket sendiri memiliki potensi untuk menjadi sumber energi terbaharukan jika briket diproduksi menggunakan biomassa yang dipanen atau residu agrikultur yang berkelanjutan [19].

Kualitas briket arang pada umumnya ditentukan berdasarkan sifat fisik dan kimianya antara lain ditentukan oleh kadar air, kadar abu, kadar zat menguap, kadar karbon terikat, kerapatan, keteguhan, tekan, dan niali kalor. Sedangkan standar kualitas secara baku untuk briket arang Indonesia mengacu pada Standar Nasional Indonesia (SNI) dan juga mengacu pada sifat briket arang buatan Jepang, Inggris, dan Amerika. Baku mutu kualitas briket disajikan pada Tabel 1.

Tabel 1.

Tabel Standar Briket Pada Negara Jepang, Inggris, Amerika dan Indonesia

\begin{tabular}{lcccc}
\hline \multicolumn{1}{c}{ Sifat Briket } & Jepang & Inggris & Amerika & SNI \\
\hline $\begin{array}{l}\text { Kadar air (moisture } \\
\text { content) \% }\end{array}$ & $6-8$ & 3,6 & 6,2 & 8 \\
$\begin{array}{l}\text { Kadar zat menguap } \\
\text { (volatile matter) } \%\end{array}$ & $15-30$ & 16,4 & $19-28$ & 15 \\
$\begin{array}{l}\text { Kadar abu (ash } \\
\text { content)\% }\end{array}$ & $3-6$ & 5,9 & 8,3 & 8 \\
$\begin{array}{l}\text { Kadar karbon terikat } \\
\text { fixed carbond }\end{array}$ & $60-80$ & 75,3 & 60 & 77 \\
$\begin{array}{l}\text { content)\% } \\
\text { Kerapatan (density) } \\
\text { g/cm3 }\end{array}$ & $1,0-1,2$ & 0,46 & 1 & - \\
$\begin{array}{l}\text { Keteguhan tekanan } \\
\text { g/cm2 }\end{array}$ & $60-65$ & 12,7 & 62 & - \\
$\begin{array}{l}\text { Nilai kalor (caloriffc } \\
\text { value) cal/g }\end{array}$ & $6000-7000$ & 7289 & 6230 & 5000 \\
\hline \hline
\end{tabular}

\section{METODOLOGI}

\section{A. Lokasi dan Waktu Penelitian}

Penelitian dilakukan pada bulan Maret sampai Mei 2017 di Laboratorium Biosains dan Teknologi Tumbuhan,
Departemen Biologi, Fakultas Ilmu Alam dan Laboratorium Teknologi Biofuel, Atsiri dan Nabati Departemen D3 Teknik Kimia, Institut Teknologi Sepuluh Nopember Surabaya.

\section{B. Perlakuan Awal (Pretreatment)}

Bahan yang akan digunakan cangkang kelapa sawit (Elaeis guineensis) dan ampas biji kelor (Moringa oleifera).Pada proses ini bahan dibersihkan terlebih dahulu dari bahan pengotor seperti tanah dan kotoran-kotoran yang menempel. Selanjutnya bahan dikeringkan untuk memudahkan proses pembakaran atau karbonisasi.

\section{Proses Karbonisasi}

Cangkang kelapa sawit yang sudah kering diarangkan menggunakan furnace $350^{\circ} \mathrm{C}$ selama $2 \mathrm{jam}$. Setelah menjadi arang, dikeluarkan dari furnace kemudian diletakkan di dalam desikator hingga dingin.

\section{Penyaringan Bahan}

Arang yang telah terbentuk pada proses karbonisasi selanjutnya dihaluskan dengan menggunakan mortar dan diayak sehingga diperoleh serbuk arang dengan ukuran 100 mesh, kemudian disimpan dalam wadah tertutup.

\section{E. Pembuatan Briket dan Pencampuran Bahan Perekat}

Arang cangkang kelapa sawit dan ampas biji kelor dibuat dengan variasi cangkang kelapa sawit terkarbonasi dicampur dengan ampas biji kelor yang tidak terkarbonasi, serta sebagai kontrol dibuat dengan variasi cangkang kelapa sawit dan ampas biji kelor yang terkarbonisasi. Masing-masing perlakuan tersebut dibuat lima konsentrasi yaitu 100:0, 75:25, 50:50, 25:75 dan 0:100. Perekat kanji dibuat dengan cara memasak tepung kanji dengan air dengan perbandingan 1:10, 1gram tepung kanji dengan 10 liter air hingga membentuk gel. Perekat kanji yang telah terbentuk selanjutnya dicampur dengan bahan pembuat briket dengan penambahan perekat sebesar $10 \%$ pada tiap perlakuan perbandingan bahan briket yang digunakan.

\section{F. Pencetakan}

Hasil adonan briket diletakkan pada cetakan berbentuk silinder, kemudian dipadatkan dengan menggunakan mesin cetak briket. Briket yang telah dibentuk kemudian dipadatkan dengan menggunakan alat press. Masing-masing perlakuan konsentrasi diberi tekanan $25 \mathrm{~kg} / \mathrm{m}^{2}$. Pembuatan briket dilakukan dengan menggunakan alat pencetak briket yang berdiameter $5 \mathrm{~cm}$.

\section{G. Pengeringan}

Briket arang yang dihasilkan kemudian dikeringkan dalam oven pada suhu $60^{\circ} \mathrm{C}$ selama $3 \times 24$ jam. Briket yang telah dikeringkan dikemas dalam kantong plastic dan ditutup rapat untuk menjaga agar briket tetap dalam keadaan kering [1].

\section{H. Uji Kadar Air}

Moisture atau kadar air adalah kandungan air yang terdapat pada briket. Kadar air dapat ditentukan dengan cara menimbang cawan porselin kosong kemudian sampel briket dimasukkan ke cawan. Sampel dimasukkan ke dalam oven yang telah diatur suhunya sebesar $105^{\circ} \mathrm{C}$ selama 3 jam. Cawan dikeluarkan dari oven dan didinginkan dalam 
desikator, kemudian ditimbang bobotnya [1]. Berikut adalah rumus perhitungan kadar air yang terdapat pada briket:

$$
\text { Moisture }(\%)=\frac{M 1-M 2}{M 1} \times 100 \%
$$

Keterangan: $\quad$ M1 = Berat cawan kosong + berat sampel sebelum pemanasan $(\mathrm{g})$

M2= Berat cawan kosong + berat sampel setelah pemanasan $(\mathrm{g})$

\section{Penentuan Kadar Abu (ash)}

Penentuan kadar abu dilakukan dengan cara mengeringkan cawan porselin, selanjutnya cawan ditimbang bobot kosongnya. Kemudian ke dalam cawan kosong tersebut dimasukkan sampel. Cawan yang telah berisi sampel selanjutnya dimasukkan ke dalam furnace dengan suhu $950^{\circ} \mathrm{C}$ selama 4 jam sampai sampel menjadi abu. Selanjutnya cawan diangkat dari dalam tanur dan didinginkan di dalam desikator, lalu ditimbang. Kadar abu dapat dihitung dengan menggunakan rumus:

$$
\text { Kadar abu }=\frac{\mathrm{A}}{\mathrm{B}} \times 100 \%
$$

\section{Keterangan: $\quad \mathrm{A}=$ Berat abu $(\mathrm{g})$}

$\mathrm{B}=$ Berat sampel $(\mathrm{g})$

\section{J. Penentuan Kadar Zat yang Hilang (Volatile Matters)}

Cara menentukan kadar zat yang hilang dilakukan dengan cara menimbang dengan teliti sebanyak 1 sampel ke dalam cawan kosong tersebut. Cawan selanjutnya ditutup dan dimasukkan ke dalam oven dengan suhu $950^{\circ} \mathrm{C}$ selama 7 menit. Kadar zat yang hilang dapat dihitung dengan menggunakan rumus:

$$
\mathrm{vm}=\frac{W 1-W 2}{W 1} \times 100 \%
$$

Keterangan: $\quad \mathrm{W} 1=$ Berat sampel awal $(\mathrm{g})$

$\mathrm{W} 2=$ Berat sampel setelah pemanasan $(\mathrm{g})$

\section{K. Karbon Tetap (Fixed carbon)}

Fixed carbon dihitung dari 100\% dikurangi dengan kadar air (moisture) dikurangi kadar abu, dikurangi volatile matter,

$$
\mathrm{FC}(\%)=100 \%-(\mathrm{M}+\mathrm{A}+\mathrm{V})
$$

$$
\begin{array}{ll}
\text { Keterangan: } & M=\text { moisture (kadar air) } \\
& A=\text { ash (kadar abu) } \\
& V=\text { volatile (kadar zat hilang) }
\end{array}
$$

\section{Uji Kalor}

Nilai kalor dihitung menggunakan alat bomb calorimeter. Pengujian kalor dilakukan dengan cara menimbang briket 0,15 gram dan diletakkan dalam cawan, kemudian dimasukkan ke dalam tabung dan dimasukkan oksigen dengan tekanan 30 bar. Tabung diletakkan dalam calorimeter, kemudian air pendingin dimasukkan dan kalori meter ditutup. Pengaduk air pendingin dihidupkan dan dicatat temperaturnya, penyalaan dilakukan selama 5 menit dan dicatat kenaikan suhunya. Perhitungan dilakukan dengan rumus:

Nilai Kalor $=\mathrm{T} 2-\mathrm{T} 1-0,05 \times \mathrm{Cv}$ x 0,24

Keterangan: $\quad \mathrm{T} 1=$ suhu air mula-mula $\left({ }^{\circ} \mathrm{C}\right)$

$\mathrm{T} 2=$ suhu setelah pembakaran $\left({ }^{\circ} \mathrm{C}\right)$

$\mathrm{Cv}=$ berat jenis calorimeter $=73529,6$

$(\mathrm{kJ} / \mathrm{kg})$

$0,05=$ kenaikan temperatur kawat penyala

1 Joule $=0,24 \mathrm{kal}$

\section{Laju Pembakaran}

Pengujian ini dilakukan dengan cara menyalakan briket dan diukur menggunakan stopwatch hingga beriket padam menjadi abu.

\section{HASIL DAN PEMBAHASAN}

\section{A. Limbah Biji Moringa oleifera Sebagai Bahan Bakar}

Ampas biji Moringa oleifera merupakan limbah organik yang memiliki peluang untuk dijadikan sebagai bahan bakar briket. Limbah biji Moringa oleifera digunakan sebagai variasi bahan pembuatan briket pada penelitian ini karena limbah biji Moringa oleifera memiliki sifat difusi termal yang baik yang diakibatkan oleh tingginya kandungan selulosa dan lignin yang terdapat di dalam biji [14]. Selain itu, keberadaan biji Moringa oleifera yang berasal dari limbah pertanian maupun yang berasal dari limbah rumah tangga dan industri yang belum dimanfaatkan secara maksimal. Untuk meningkatkan penggunaan limbah biji Moringa oleifera sebagai bahan bakar alternatif maka limbah biji Moringa oleifera dapat dibuat menjadi briket. Selain hal tersebut, biji Moringa oleifera juga memiliki kadar karbon terikat yang dapat dimanfaatkan sebagai bahan pembuatan briket [21]. Karbon terikat (fixed carbon) yaitu fraksi karbon (C) yang terikat dalam arang selain fraksi air, zat menguap, dan abu. Keberadaan karbon terikat didalam briket arang dipengaruhi nilai kadar abu dan kadar menguap. Kadar nya akan bernilai tinggi apabaila kadar abu briket arang tersebut rendah [22]. Pada penelitian ini, didapatkan hasil karbon terikat yang dimiliki biji Moringa oleifera yaitu sebesar 40,93\%. Karbon terikat biji Moringa oleifera memiliki nilai terbesar dibandingakan dengan karbon terikat pada cangkang kelapa sawit. Hal ini menunjukkan bahwa limbah biji Moringa oleifera dapat digunakan sebagai bahan pembuatan briket.

B. Pengaruh Kadar Air, Kadar Abu, dan Zat yang Hilang (Volatile Matter) Terhadap Kalor yang Dihasilkan

Kadar air yang diperoleh dari penelitian ini berkisar antara 0,27-2,19\%. Keseluruhan briket yang dihasilkan dari berbagai perbandingan telah sesuai dengan SNI (SNI 016235-2000) yaitu maksimal 8\%. Kadar air terendah diperoleh pada perbandingan bahan $0 \%: 100 \%$ (cangakang:biji) yakni sebesar 0,27 dan tertinggi pada perbandingan bahan 100\% : 0\% (cangakang:biji) sebesar 2,19. Kadar air briket dipengaruhi oleh jenis bahan baku, jenis perekat dan metode pengujian yang digunakan [23]. Pada umumnya kadar air yang tinggi akan menurunkan nilai kalor dan laju pembakaran karena panas yang diberikan digunakan terlebih dahulu untuk menguapkan air yang 
terdapat di dalam briket. Pada penelitian ini semakin tinggi kadar cangkang kelapa sawit maka kadar air yang diperoleh semakin tinggi pula. Hal ini disebabkan oleh cangkang kelapa sawit memiliki kadar air yang lebih besar dibandingan dengan biji kelor yaitu sebesar 11,82\% [24]. Kadar air sangat mempengaruhi nilai kalor yang dihasilkan. Pada penelitian ini kadar air tinggi ditunjukkan pada perbandingan cangkang dan biji (100\% : 0\%) hal tersebut dikarenakan cangkang memiliki kandungan selulosa, hemiselulosan, lignin yang lebih besar dibandingan biji kelor, sehingga meskipun cangkang memiliki kadar air tinggi dibandingkan dengan biji kelor hasil kalor yang dihasilkan tetap lebih tinggi [24].

Nilai kadar abu yang dihasilkan dari penelitian ini yaitu berkisar antara $2,01 \%-1,81 \%$. Hasil yang diperoleh sesuai dengan SNI yaitu kadar abu briket maksimal 8\%. Kadar abu terendah diperoleh pada perbandingan cangkang dan biji kelor yaitu sebesar $1,81 \%$ dan kandungan abu tertinggi diperoleh pada prosentase cangkang dan biji kelor yaitu sebesar 2,01\%. Penentuan kadar abu dimaksudkan untuk mengetahui bagian yang tidak terbakar yang sudah tidak memiliki unsur karbon lagi setelah briket dibakar. Kadar abu sebanding dengan kandungan bahan anorganik yang terdapat di dalam briket [6]. Kadar abu meningkat dengan meningkatnya kadar cangkang kelapa. Cangkang memiliki kandungan bahan anorganik silika $\left(\mathrm{SiO}_{2}\right), \mathrm{MgO}$ dan $\mathrm{Fe}_{2} \mathrm{O}_{3}$, $\mathrm{AlF}_{3}, \mathrm{MgF}_{2}$ dan $\mathrm{Fe}$ lebih tinggi dibandingkan dengan biji kelor sehingga memiliki kadar abu yang lebih tinggi pula [24].

Kadar zat yang hilang (Volatile matter) adalah zat yang dapat menguap sebagai hasil dekomposisi senyawa-senyawa yang masih terdapat di dalam briket arang selain air, karbon terikat dan abu [25]. Kadar zat yang hilang yang diperoleh pada penelitian ini berkisar antara 38,85\% - 29,81\%. Hasil penelitian menunjukkan bahwa kadar zat yang hilang tidak sesuai menurut SNI. Kadar zat yang hilang yang diperoleh pada penelitian ini semakin bertambah seiring dengan semakin bertambahnya kadar biji kelor. Hal ini disebabkan adanya kandungan zat-zat menguap seperti $\mathrm{CO}, \mathrm{CO}_{2}, \mathrm{H}_{2}$, $\mathrm{CH}_{4}$ dan $\mathrm{H}_{2} \mathrm{O}$ yang terdapat pada biji kelor yang digunakan ikut menguap. Kandungan zat menguap yang tinggi akan menimbulkan banyak asap pada saat briket dinyalakan. Kandungan asap yang tinggi disebabkan oleh adanya reaksi antara karbon monoksida (CO) dengan turunan alkohol [26]

Tabel 2.

Tabel Pengaruh Kadar Air, Kadar Abu, dan Zat yang Hilang (Volatile Matter) Terhadap Kalor yang Dihasilkan

\begin{tabular}{lcccc}
\hline \hline Cangkang : Biji & kadar air & kadar abu & $\begin{array}{c}\text { volatile } \\
\text { matter }\end{array}$ & $\begin{array}{c}\text { kalor } \\
\text { kal/g }\end{array}$ \\
\hline $100 \%: 0 \%$ & $2,19 \%$ & $2,01 \%$ & $29,81 \%$ & 5126,1 \\
$75 \%: 25 \%$ & $0,96 \%$ & $1,83 \%$ & $31,06 \%$ & 4962,7 \\
$50 \%: 50 \%$ & $0,83 \%$ & $1,96 \%$ & $34,55 \%$ & 4851,4 \\
$25 \%: 75 \%$ & $0,97 \%$ & $1,88 \%$ & $36,9 \%$ & 4691,6 \\
$0 \%: 100 \%$ & $0,27 \%$ & $1,81 \%$ & $38,85 \%$ & 4568,3 \\
SNI & $8 \%$ & $8 \%$ & $15 \%$ & 5000 \\
\hline \hline
\end{tabular}

\section{Hubungan Antara laju Pembakaran dan Penambahan} Biji Moringa oleifera Terhadap Kualitas Briket

Hasil Pengujian laju pembakaran dilakukan untuk mengetahui efektifitas dari suatu bahan bakar. Hal ini untuk mengetahui sejauh mana kelayakan dari bahan bakar yang diuji sehingga dalam aplikasinya nanti bisa digunakan [27]. Hasil pada pengujian ini variasi campuran antara cangkang kelapa sawit dan biji kelor yang paling tinggi laju pembakarannya yaitu pada perbandingan 100\% : 0\% sebesar $0,142 \mathrm{gr} /$ detik. Sedangkan yang paling rendah terdapat pada perbandingan 0\% : $100 \%$ sebesar $0,097 \mathrm{gr} /$ detik, pada pebandingan lainnya menunjukkan hasil laju pembakaran tidak berbeda jauh yakni sebesar $0,103 \mathrm{gr} / \mathrm{s}$ pada konsentrasi $25 \%: 75 \%, 0,121 \mathrm{gr} / \mathrm{s}$ pada konsentrasi $50 \%$ : 50\%, dan $0,118 \mathrm{gr} / \mathrm{s}$ pada konsentrasi $75 \%$ : $25 \%$. Faktor yang mempengaruhi hal ini dikarenakan konsentrasi antara cangkang kelapa sawit dan biji kelor yang berbeda - beda yang terdapat dalam campuran briket, dimana dalam cangkang memiliki kandungan bahan anorganik maupun organik yang lebih tinggi dibandingan dengan biji kelor yang mempengaruhi laju pembakaran dari briket yang dihasilkan, sehingga penambahan limbah biji kelor tidak berpengaruh terhadap tingginya laju pembakaran dan cenderung memiliki nilai yang lebih kecil dibandingan dengan konsentrasi variasi yang lain dengan kandungan cangkang kelapa sawit yang lebih besar. Adapun hubungan antara berbagai konsentrasi cangkang kelapa sawit dan biji kelor terhadap laju pembakaran briket ditampilkan pada Tabel 3.

Tabel 3.

Tabel Hubungan Antara laju Pembakaran dan Penambahan Biji Moringa oleifera Terhadap Kualitas Briket

\begin{tabular}{lc}
\hline \hline Cangkang : Biji & laju pembakaran g/s \\
\hline $100 \%: 0 \%$ & 0,142 \\
$75 \%: 25 \%$ & 0,118 \\
$50 \%: 50 \%$ & 0,121 \\
$25 \%: 75 \%$ & 0,103 \\
$0 \%: 100 \%$ & 0,097 \\
\hline \hline
\end{tabular}

\section{Karbon Tetap (Fix Carbon)}

Fix carbon merupakan bagian dari briket selain kadar air, kadar abu dan volatile matter. Fix carbon merupakan salah satu penentu kualitas briket, semakin tinggi kadar karbon tetap menunjukkan semakin baik kualitas briket [28]. Hasil pengujian ini variasi campuran antara cangkang kelapa sawit dan biji kelor yang paling tinggi karbon tetapnya yaitu pada perbandingan $75 \%: 25 \%$ sebesar $66,15 \%$. sedangkan paling rendah pada perbandigan 0\%:100\% sebesar 59,07\%, Kadar karbon tetap yang diperoleh pada penelitian ini berkisar antara 66,15\% - 59,07\%. Kadar karbon tetap yang diperoleh pada penelitian ini semakin bertambah seiring dengan semakin bertambahnya kadar cangkang kelapa sawit.

Tabel 4.

Tabel Data karbon tetap (Fix carbon)

\begin{tabular}{lc}
\hline \hline Cangkang : Biji & fix carbon $\%$ \\
\hline $100 \%: 0 \%$ & 65.99 \\
\hline \hline
\end{tabular}




\begin{tabular}{ll}
\hline \hline $75 \%: 25 \%$ & 66.15 \\
$50 \%: 50 \%$ & 62.66 \\
$25 \%: 75 \%$ & 60.25 \\
$0 \%: 100 \%$ & 59.07 \\
\hline \hline
\end{tabular}

\section{KESIMPULAN}

Berdasarkan hasil penelitian didapatkan hasil briket dengan nilai kalor terbesar dalam perbandingan komposisi cangkang:biji kelapa sawit dengan nilai 100\%:0\% sebesar $5126.1 \mathrm{kal} / \mathrm{gr}$, nilai tersebut merupakan nilai yang telah memenuhi Standar Nasional Indonesia (SNI) yang ditetapkan, sebesar $5000 \mathrm{kal} / \mathrm{gr}$.

\section{SARAN}

Proses pembuatan briket dapat dilakukan dengan variasi bahan dan perekat yang berbeda konsentrasi. Oleh karena itu, perlu dilakukan penelitian lebih lanjut terkait pembuatan briket dengan kombinasi bahan dan perekat yang berbeda, serta dilakukan uji daya tahan briket serta penerapan pada kompor briket.

\section{DAFTAR PUSTAKA}

[1] D. Maryono, "Pembuatan dan Analisis Mutu Briket Arang Tempurung Kelapa Ditinjau dari Kadar Kanji," J. Chem., vol. 14, pp. 74-83, 2013

[2] P. J, "Pembuatan Briket Dari Limbah Sortiran Biji Kakao (Theobroma cacao)," Universitas Hasanudin, 2012

[3] P. Daud, "Karakteristik Termal Briket Arang Kulit Buah Kakao," J. Mek., vol. 2, no. 1, pp. 23-31, 2011.

[4] Martynis, "Pembuatan Biobriket Dari Limbah Cangkang Kakao," J. Litbang Ind., vol. 2, no. 2, pp. 35-41, 2012.

[5] S. D. dan R. H. Sudradjat R, "Teknik Pembuatan dan Sifat Briket Arang dari Tempurung dan Kayu Tanaman Jarak Pagar (Jatropha curcas. L)," J Penelit Has. Hutan, vol. 24, pp. 227-240, 2006.

[6] A. Triono, "Karakteristik briket arang dari campuran serbuk gergajian kayu afrika dan sengon dengan penambahan tempurung kelapa," Intitut Pertanian Bogor, 2006.

[7] W. DS, "Karakteristik Briket Arang dari Serbuk Gergaji dengan Penambahan Arang Cangkang Kelapa Sawit," Universitas Sumatera Utara, 2009.

[8] W. Sunaryo, Wahyu, "Penelitian Nilai Kalor Bahan Bakar Biomassa pada Limbah kotoran Hewan," J. Aptek, vol. 6, no. 1, pp. 87-959, 2014.

[9] Munthe, "Pemanfaatan Cangkang Kelapa Sawit dan Limbah Kelapa Sawit (sludge) Sebagai Bahan Baku Pembuat," vol. 3, no.
4, pp. 518-525, 2015

[10] Y. Sinya, The Asian Biomass Handbook A Guide for Biomass Production and Utilization, Japan, The University of Tokyo. 2008.

[11] Mulia, "Pemanfaatan Tandan Kosong Kelapa Sawit dan Cangkang Kelapa Sawit sebagai Briket Arang," Universitas Sumatera Utara, 2007.

[12] Kamal, "Karakteristik dan Potensi Pemanfaatan Limbah Sawit," Institut Teknologi Bandung, 2012.

[13] Ningtyas, "Pembuatan dan Karakterisasi Biodiesel Minyak Biji Kelor (Moringa oleifera)," UNESA, 2009.

[14] D. P. Nasir, S., D. Fatina, "Pemanfaatan Ekstrak Biji Kelor (Moringa oleifera) untuk Pembuatan Bahan Bakar Nabati," 29 34, 2010 .

[15] B. A. A. dan G. B. Murtala, Ahmed M, "Biomass Resource as a Source of Sustainable Energy Production in Developing Countries," J. Appl. Phytotechnology Enviromental Sanit., vol. 1, no. 2, pp. 103-112, 2012.

[16] P. Mishra, "Prafull Singh dan Prashant Baredar, Impact of Moisture Level in Atmosphere on Biomass Gasification: A Bioenergy for Sustainable Development," Int. J. Enviromental Sci., vol. 1, no. 4, pp. 640-644, 2010.

[17] Briens, "Biomass Valorization for Fuel and Chemicals Production," Int. J. Chem. React. Enginering, vol. 6, 2008.

[18] O. I. Martin, "Enhacing the Properties of Coal Briquette using Spear Grass (Imperata Cylindrica) and Elephant Grass (Pennisetum Purpureum)," Nnamdi Azikiwe University, 2010.

[19] Ferguson, "Briquette Businesses in Uganda The potential for briquette enterprises to address the sustainability of the Ugandan biomass fuel marke," in GVEP International, 2012.

[20] C. Dahlman, J., \& Forst, "Technologies Demonstrated at ECHO: Briquette presses for alternative fuel use," p. 239, 2001.

[21] M. Abdulkarin, SM dan Wyat, "Sensory and Physicocemical Qualities of Palm Oil and Sesame Oil Blends during Frying of Banana Chips," Universiti Putra Malaysia, 2010.

[22] Hartoyo, "Pembuatan Aranag dan Briket Arang secara dari serbuk gergaji dan limbah industry perkayuan," 1983.

[23] A. Gandhi, "Pengaruh Variasi Jumlah Campuran Perekat Terhadap Karakteristik Briket Arang Tongkol Jagung," Universitas Negeri Semarang, 2009.

[24] M. K. Sari, "Potensi Dan Peluang Kelayakan Ekspor: Kelayakan Ekspor Arang Tempurung Kelapa (Coconut shell charcoal) di Kabupaten Banyumas," Mediagro, pp. 69-82, 2011.

[25] E. Budi, "Tinjauan Proses Pembentukan dan Penggunaaan Arang Tempurung Kelapa sebagai Bahan Bakar," J. Penelit. Sains, vol. 14 , no. 4, 2011.

[26] A. Tirono, M. dan Sabit, "Efek Suhu pada Proses Pengarangan terhadap Nilai Kalor Arang Tempurung Kelapa (Coconut Shell Charcoal)," UIN Maulana Malik Ibrahim Malang, 2011.

[27] R. Wahyusi, K., Dewati, R., Ragilia, "Briket Arang Kulit Kacang Tanah dengan Proses Karbonisasi," UPN, 2012.

[28] S. Dkk, "Pengaruh Komposisi dan Ukuran Serbuk Briket yang Terbuat dari Batubara dan Jerami Padi terhadap Karakteristik Pembakaran," J. Sainstech Politek. Indonusa Surakarta, vol. 2, no. 2, 2014. 